\title{
Influence of Roasting of Shea Kernels on Their Fat Content and Some Quality Characteristics of Shea Butter
}

\author{
Fernande G. HONFO \\ Food Quality and Design, Department of Agrotechnology and Food Sciences, \\ Wageningen University, P.O. Box 17, 6700 AA Wageningen, The Netherlands \\ Faculté des Sciences Agronomiques, Université d'Abomey-Calavi, 01 BP 526 Cotonou, \\ Benin \\ Ecole Polytechnique d'Abomey-Calavi, Université d'Abomey-Calavi, 01 BP 526 \\ Cotonou, Benin
}

Anita R. LINNEMANN (Corresponding author)

Food Quality and Design, Department of Agrotechnology and Food Sciences, Wageningen University, P.O. Box 17, 6700 AA Wageningen, The Netherlands

\section{Meng GUO}

Food Quality and Design, Department of Agrotechnology and Food Sciences, Wageningen University, P.O. Box 17, 6700 AA Wageningen, The Netherlands

\section{Noel AKISSOE}

Faculté des Sciences Agronomiques, Université d'Abomey-Calavi, 01 BP 526 Cotonou, Benin

\section{Mohamed M. SOUMANOU}

Ecole Polytechnique d'Abomey-Calavi, Université d'Abomey-Calavi, 01 BP 526 Cotonou, Benin 
Martinus A. J. S. van BOEKEL

Food Quality and Design, Department of Agrotechnology and Food Sciences, Wageningen University, P.O. Box 17, 6700 AA Wageningen, The Netherlands

Received: March 8, 2017 Accepted: September 23, 2017 Published: November 15, 2017

doi:10.5296/jfs.v6i1.10881ＵRL: htts://doi.org/10.5296/jfs.v6i1.10881

\begin{abstract}
In shea production zones in Sub-Saharan Africa, shea butter is mostly produced by women using traditional methods. Improvement of their practices would allow them to obtain better monetary returns for their activities. Roasting of crushed shea kernels is a processing step that has a major influence on the quantity and quality of extracted shea butter. Using a central composite face-centered design (CCFD), the effect of roasting, specifically roasting time and temperature was investigated. Both factors influenced fat content $(44-53 \% \mathrm{dw})$ of the crushed kernels; colour characteristics and free fatty acid (FFA) content $(0.5-3 \%)$ of the butter. In shea butter from differently roasted kernels, 58 volatile compounds were identified, of which 11 were quantitatively dominant, against 27 compounds in butter from unroasted kernels. The ideal practice according to the CCFD model is roasting at $171{ }^{\circ} \mathrm{C}$ for $15 \mathrm{~min}$, which resulted in a fat content of $49 \% \mathrm{dw}$ of the kernels, a butter yield of $32 \%$, a FFA of $1.2 \%$ of the butter, and a peroxide value of $3.2 \mathrm{meq} \mathrm{O}_{2} / \mathrm{kg}$. This optimum roasting time is appreciably shorter than the current practice, suggesting that the use of firewood during traditional processing can be reduced.
\end{abstract}

Keywords: Roasting, Volatile compounds, SPME-GC-MS, Carbonyls, Hexanal, FFA

\title{
1. Introduction
}

The economy of Benin is based on the agricultural sector, in which about $70 \%$ of the population is involved. Cotton has been the most important export crop for a long time, providing $90 \%$ of the agricultural export value. Due to national and international difficulties in cotton chains, the Beninese government decided to encourage diversification of agricultural export commodities. Among the selected products was the produce of the shea tree (Vitellaria paradoxa). In Benin, shea kernels represent the third export commodity after cotton and cashew nuts (Elias \& Carney, 2004). From the shea kernels, butter can be extracted, which to date is mostly done by traditional methods. Shea butter and shea kernels play a significant role in poverty alleviation (Elias \& Carney; 2004 Master et al., 2004), not only in Benin but also in other Sub-Saharan African countries where shea trees occur. A first step in the empowerment of local women and women's groups to produce shea-based products for the international market is to determine how local low-input production impacts the quality of shea kernels and butter, and subsequently how local processing practices can be optimised. 


\section{Macrothink}

Shea butter is used as cooking and frying fat in the production zones, while it is used for medical and cosmetic purposes as well as a cocoa butter substitute in chocolate at an international level. For the various purposes, different qualities of shea butter are used: as cooking fat, more flavourful butters are preferred by consumers (Alander \& Andersson, 2002). To substitute cocoa butter, shea butter without odour and with high palmitic and stearic acid contents is preferred due to its crystallisation and melting characteristics essential in chocolate confectionery (Lipp \& Adam, 1998). White or light coloured shea butter with a high amount of unsaponifiables is desired for personal care products (i.e. cosmetics, moisturisers, creams) (Di Vincenzo et al., 2005); the unsaponifiable fraction is a characteristic that makes shea butter special due to its antioxidant and claimed anti-inflammatory properties (Maranz \& Wiesman, 2004). Apart from these desired attributes, and based on free fatty acids (FFA), peroxide value and moisture content, three shea butter grades are recognised and approved by shea production countries for international trade: the first grade refers to unrefined shea butter, obtained by manual or mechanical methods. It is the highest quality of shea butter, mainly used in the cosmetic industry; its FFA percentage has to be less than $1 \%$, the peroxide value less than 10 meq $\mathrm{O}_{2} / \mathrm{kg}$ and the moisture content less than $0.05 \%$. The second grade concerns unrefined shea butter used for food purposes and as edible oils; its FFA content must be between 1 and 3\%, the peroxide value between 11 and 15 meq $\mathrm{O}_{2} / \mathrm{kg}$ and the moisture content between 0.06 and $0.5 \%$. The third grade of shea butter is mainly used in the soap industry or is refined (USAID/WATH, 2005; NB 04.02.001, 2006).

Among the traditional unit operations in shea kernel processing, roasting is reported to be critical for butter quality and yield (Womeni, 2004; Kapseu et al., 2007). Crushed shea kernels are commonly dry roasted for 30 - 60 min in a pot with direct heating by firewood (Honfo et al., 2012). Roasting is performed to facilitate fat extraction and to improve sensory characteristics, such as smell, colour, taste, and flavour of butter (Honfo et al., 2012), although it may also affect the overall flavour in a negative way. Certain desirable aroma compounds may be lost and compounds that cause off flavours formed, when roasting is not done properly (Krysiak, 2002). In other words, insufficient heating might reduce the yield of oil, and too high temperatures may lead to undesirable volatile compounds derived from peroxides or hydroperoxides (Nawar, 1998; Frankel, 1985; Krysiak, 2002; Krysiak \& Motyl-Patelska, 2006). Most volatile compounds in shea butter can be characterised as fat degradation products, viz. ketones, aldehydes, hydrocarbons, and alcohols (Choe \& Min, 2006). Furthermore, sugars can condense with free amino acids, peptides, or proteins leading to the formation of brown Maillard reaction products (Krysiak \& Motyl-Patelska, 2006).

Previous studies on the processing of shea nuts into butter (Womeni, 2004; Kapseu et al., 2007; Bup et al., 2011) have not assessed the relationship between roasting time and temperature during shea processing on the yield and quality, including the volatile compounds of the butter. The main objective of this study was therefore to assess the impact of roasting conditions of shea kernels on fat yield, and on the FFA percentage, peroxide value and volatile compounds of the butter to optimise production practices in rural, low-input settings. 


\section{Al Macrothink}

\section{Materials and Methods}

\subsection{Experimental Design}

The response surface methodology is a statistical method that uses quantitative data derived from an appropriate experimental design with quantitative factors to estimate the relationship between a response and the factors in order to optimize processes or products (Giovanni, 1983). In this study, a central composite face-centered design (CCFD) with 2 factors (Montogomery, 2001) was used to assess the simultaneous effect of roasting time (15-45 min) and roasting temperature $\left(120-180{ }^{\circ} \mathrm{C}\right)$ of crushed shea kernels on quality parameters of the resulting butter and to determine the optimum roasting processing conditions. Ranges of roasting time and temperatures were chosen to reflect the actual roasting practices of shea butter processors in most shea production zones, including Benin (Honfo et al., 2012). The design generated 13 combinations (Table 1) and each of them was duplicated, giving a total of 26 combinations.

Table 1. Different combinations of roasting time and temperature generated by the central composite face-centered design

\begin{tabular}{ccc}
\hline Treatment & Roasting time: $X_{I}$ (Minute) & Roasting temperature: $X_{2}\left({ }^{\circ} \mathrm{C}\right)$ \\
\hline 1 & 30 & 150 \\
2 & 15 & 150 \\
3 & 45 & 120 \\
4 & 15 & 120 \\
5 & 30 & 120 \\
6 & 15 & 180 \\
7 & 30 & 150 \\
8 & 45 & 150 \\
9 & 30 & 150 \\
10 & 30 & 180 \\
11 & 30 & 150 \\
12 & 45 & 180 \\
13 & 30 & 150 \\
\hline
\end{tabular}

\subsection{Experimental Processing}

Dried shea kernels were bought at the local market of Bassila $\left(9^{\circ} 00 \mathrm{~N}\right.$ and $\left.1^{\circ} 40 \mathrm{E}\right)$, a location in Borgou Department, North-Benin. The characteristics of these kernels were: fat content $(42-49 \% \mathrm{dw})$, moisture content (7-9\%), and FFA percentage (6-7\%). The kernels were cleaned, sun-dried for 4 hours, sorted and crushed at the laboratory of the Nutrition and Food Science Department of the University of Abomey-Calavi, Benin. The crushed kernels were roasted according to the experimental treatments. Once the oven had reached the desired temperature, $500 \mathrm{~g}$ of crushed kernels were spread on three trays $(48 \mathrm{~cm} \mathrm{x} 35 \mathrm{~cm})$ and put in the oven. The time of roasting was measured from the moment when the temperature reached the desired temperature after putting the trays in the oven. Roasted kernels were cooled at room temperature before processing them into butter by milling with an electric milling 


\section{MInstitute ${ }^{\text {Mink }}$}

machine (Kenwood blender) to get a paste which was churned with water ( 1 volume of paste against 4 volumes of water). The creamy, fatty layer obtained after churning was washed three times and subsequently heated. The oil was washed and heated again to remove particles and mucilage from the first stage of heating. The resulting oil was then filtered and left to cool. Samples were taken from the roasted kernels and the butters. Samples were packed in plastic containers and stored at $4{ }^{\circ} \mathrm{C}$ until analysis. Two independent samples were prepared for each treatment.

\subsection{Characterization of Shea Kernels and Butter}

Fat content of kernels, butter yield, FFA percentage, peroxide value and volatile compounds were the quality parameters measured. Fat content of shea kernels was determined by extraction in a Soxhlet apparatus using petroleum ether as solvent (AOAC, 2002). Yield of shea butter was expressed on wet weight as percentage of the mass of the filtered oil (butter) on the mass of kernels used. Colour parameters (brightness $L^{*}$ and yellowness $b^{*}$ ) of the butter samples were measured with a Minolta CR-410 (Konica Minolta Optics, INC, Japan). FFA percentage was determined by titration and calculated as oleic acid percentage (NB ISO $660,2006)$. Titration was also used to determine peroxide values (NB ISO 3960, 2006). Each parameter was tested in triplicate.

Volatile compounds in shea butter were assessed by Solid-Phase Micro-Extraction Gas-Chromatography and Mass-Spectrometry (SPME GC-MS) according to Bail et al. (2009a) and Krist et al. (2006). SPME sampling was done by putting two grams of shea butter in vials that were tightly closed with a septum by using a GC crimper and extracted isothermally for $10 \mathrm{~h}$ at room temperature using a preconditioned Supelco $573482 \mathrm{~cm}, 50 / 30$ $\mathrm{mm}$ DVB/Carboxen/PDMS Stable-Flex fibre for analysing volatile compounds. After sampling, the SPME device was immediately placed into a splitless-mode injection port of a GC-MS instrument (Thermo Scientific DSQ II). Volatile compounds were separated using a Rxi-5ms GC column (60 m length x $0.25 \mathrm{~mm}$ inner diameter, $0.25 \mu \mathrm{m}$ film thickness). The initial temperature of the oven was held for $1 \mathrm{~min}$ at $38{ }^{\circ} \mathrm{C}$ and then increased by $2.5^{\circ} \mathrm{C} / \mathrm{min}$ to $175^{\circ} \mathrm{C}$. From that point, the temperature was increased by $50{ }^{\circ} \mathrm{C} / \mathrm{min}$ to a temperature of $220{ }^{\circ} \mathrm{C}$, which was held for $2 \mathrm{~min}$. The injector port temperature was $250{ }^{\circ} \mathrm{C}$. After using splitless modes for $2 \mathrm{~min}$, a split ratio of 1:40 was used to expurgate the system. A constant carrier gas (helium: 5.0) flow of $1 \mathrm{~mL} / \mathrm{min}$ was applied. The transfer line temperature was $250{ }^{\circ} \mathrm{C}$, which resulted in an ion source temperature of approximately $225^{\circ} \mathrm{C}$. The same GC was used to obtain the peak areas. The mass spectrometer was operated in electron impact (EI) mode with the ionization voltage set at $70 \mathrm{eV}$. The scan range was 32-250 amu. Compounds were identified by matching mass spectra with AMDIS and the XcaliburQual Browser library of standard compounds. Relative quantifications of compounds were performed as\% peak area using integration data.

\subsection{Statistical Analyses}

The experimental design was set with Minitab 16.0 software, which was also used for the analyses of variance of the different responses. A polynomial model was proposed to establish the relationship between the responses $(Y)$ and the variables $(X)$ as follows:

$$
Y=I+a X_{1}+b X_{2}+c X_{1}^{2}+d X_{2}^{2}+e X_{1} X_{2}
$$




\section{Macrothink}

Where, $I$ is a constant; $a$ and $b$ are linear effect coefficients; $c$ and $d$ are quadratic effect coefficients; and $e$ is an interaction effect coefficient. $X_{1}$ and $X_{2}$ are the variables roasting time and roasting temperature, respectively. The fitted polynomial equations were expressed by different contour plots for each quality parameter in which the surface showed the response of such parameters. Tests for lack of fit and $R^{2}$ values were used to determine the adequacy of the models.

\section{Results and Discussion}

\subsection{Quality Parameters}

Analysis of the fat content of the crushed kernels $(F C)$ gave the following regression equations for the effect of roasting time $\left(X_{1}\right)$ and roasting temperature $\left(X_{2}\right)$ :

$$
F C(\% \mathrm{dw})=49.2263+0.3822 X_{1}+0.2250 X_{2}-0.0012 X_{1}^{2}+0.0012 X_{2}^{2}-0.0017 X_{1} X_{2}
$$

This model explains $94 \%$ of the variation in the fat content of crushed kernels, which ranged from 44 to $53 \% \mathrm{dw}$. With a non-significant lack of fit with a $P$ value of 0.61 for fat content, the model could be effectively used to make accurate predictions. For instance a lack of fit is generally used to check the fitness of the regression models and a non-significant lack of fit $P$ value is linked to the adequacy of the model and the accuracy of the predictions (Montogomery, 2001). Unroasted kernels contained $42 \pm 4 \% \mathrm{dw}$ of crude fat. Linear terms of the roasting time and roasting temperature influenced the fat content positively and significantly (Table 2). The interaction of both factors had a significant and negative influence on the fat content of shea kernels. Irrespective of the roasting time, the contour plots showed a gradual increase of the fat content with increasing roasting temperature (Figure 1a). This observation might be explained by the reduction of the oil viscosity and the breakdown of cell walls and membranes of the plant material, both caused by heat (Akoh \& Min, 2008), making the fat present in the crushed kernels better extractable.

Table 2. Regression coefficients (RC), coefficient of determination (R2) and lack of fit P value for fat content of shea kernels, butter yield, $L^{*}, b^{*}$, FFA and peroxide values of shea butter obtained from kernels subjected to different roasting treatments

\begin{tabular}{lcccccc}
\hline & $\begin{array}{c}\text { Fat content }(\% \\
\mathrm{dw})\end{array}$ & $\begin{array}{c}\text { Butter yield } \\
(\%)\end{array}$ & $\mathrm{L}^{*}$ & $\mathrm{~b}^{*}$ & $\mathrm{FFA}(\%)$ & $\begin{array}{c}\text { Peroxide value }(\mathrm{meq} \\
\left.\mathrm{O}_{2} / \mathrm{kg}\right)\end{array}$ \\
\cline { 2 - 7 } Roasting time: $X_{1}$ & $0.3822^{* *}$ & $0.4228^{* *}$ & $-0.8429^{*}$ & -0.2124 & $0.2581^{* *}$ & 0.0073 \\
Roasting & $0.2250^{*}$ & -0.0062 & $1.2181^{* *}$ & $0.8180^{* *}$ & $-0.1059^{*}$ & -0.0039 \\
temperature: $X_{2}$ & & & & & & \\
$X_{1}{ }^{2}$ & -0.0012 & $-0.0086^{* *}$ & -0.0040 & -0.0012 & $-0.0016^{*}$ & 0.0007 \\
$X_{2}{ }^{2}$ & $0.0012^{* *}$ & 0.0001 & $-0.0055^{* *}$ & $-0.0032^{* *}$ & $0.0004^{*}$ & 0.0004 \\
$X_{1} X_{2}$ & $-0.0017^{* *}$ & $0.0011^{*}$ & $0.0073^{* *}$ & $0.0019^{*}$ & $-0.0011^{* *}$ & 0.0006 \\
$\mathrm{RC}$ & 49.2263 & 20.9828 & 11.8046 & -32.9767 & 7.0019 & 2.5221 \\
$\mathrm{R}^{2}$ & 0.94 & 0.93 & 0.87 & 0.86 & 0.84 & 0.78 \\
Lack of fit & 0.61 & 0.52 & 0.01 & 0.01 & 0.16 & 0.77 \\
\hline
\end{tabular}

* Significant at $P<0.05$; ** Significant at $P<0.01$. 


\section{Macrothink DInstitute ${ }^{\mathrm{TM}}$}

Butter yield increased with increasing roasting time and temperature (Figure 1b). Also, the linear and quadratic terms of roasting time as well as the interaction of the two factors had significant effects on butter yield, which varied from $27 \%$ to $34 \%$ (Table 2 ). The regression model of butter yield explained $93 \%$ of these variations with a non-significant lack of fit with a $P$ value of 0.52 . Unroasted kernels yielded $23 \pm 1 \%$ of butter, significantly less than yields from roasted kernels. In general, yields of shea butter extracted by traditional methods vary between $28 \%$ and $32 \%$ of kernels mass (Kassamba, 1997). Thus, most of the yields found in this study are in this range and some of them exceed the upper boundary of the range.
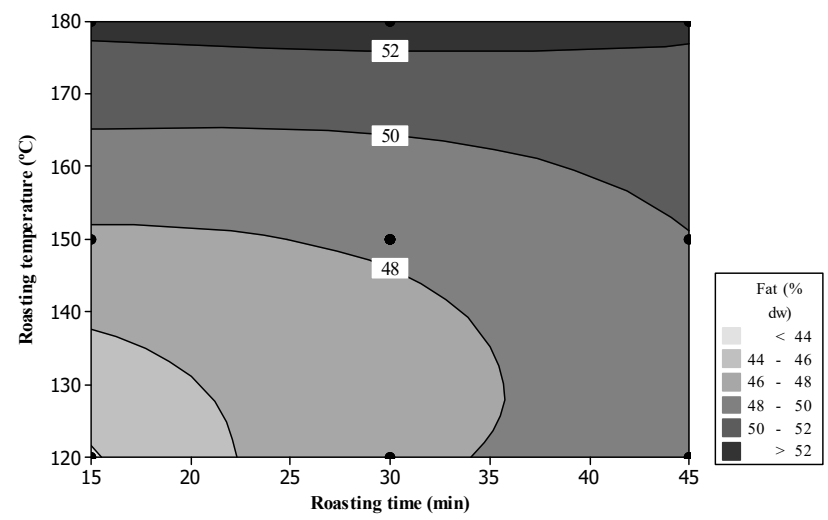

a: Fat content $(\% \mathrm{dw})$ of kernels

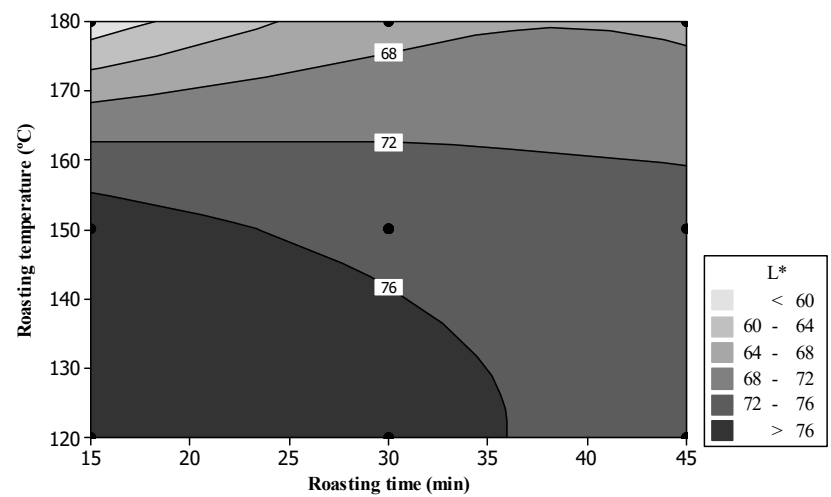

c: Brightness $\left(\mathrm{L}^{*}\right)$ of butter

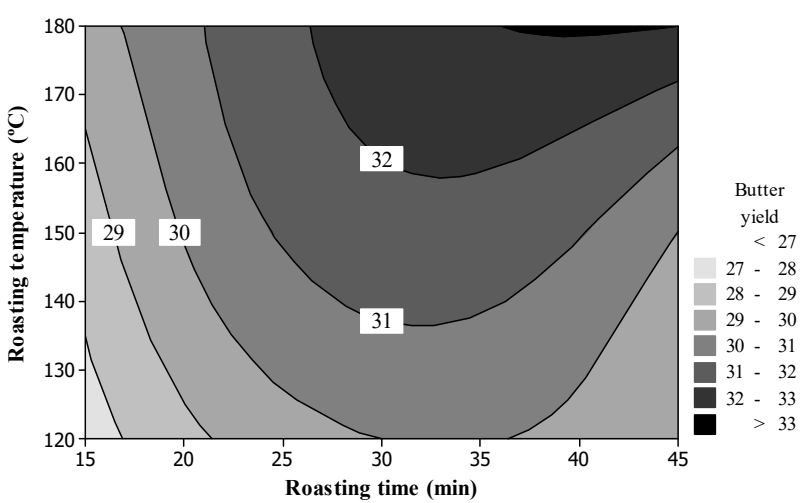

b: Yield (\%) of butter

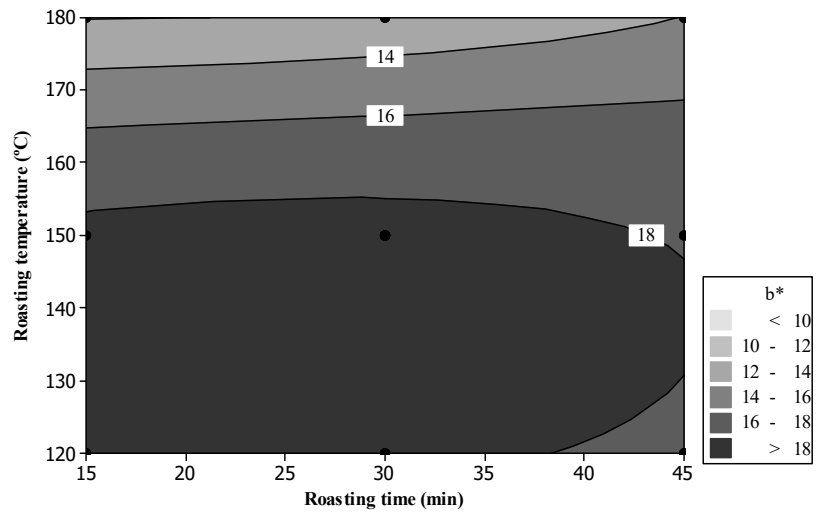

d: Yellowness $\left(b^{*}\right)$ of butter 


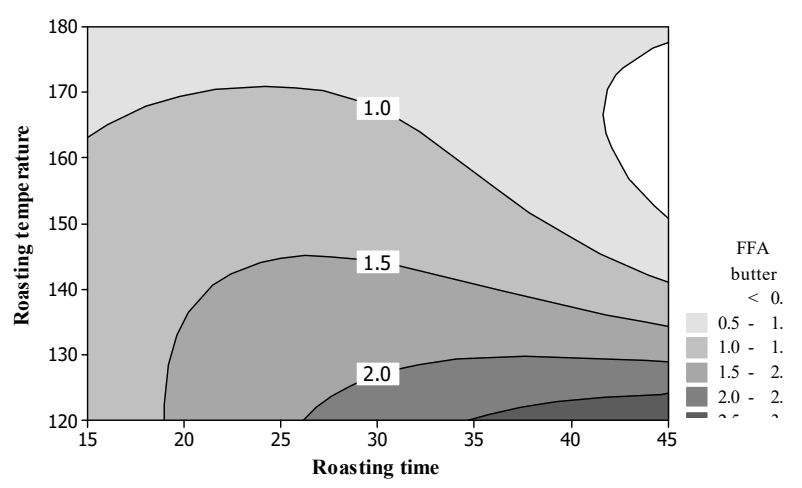

e: FFA percentage of butter

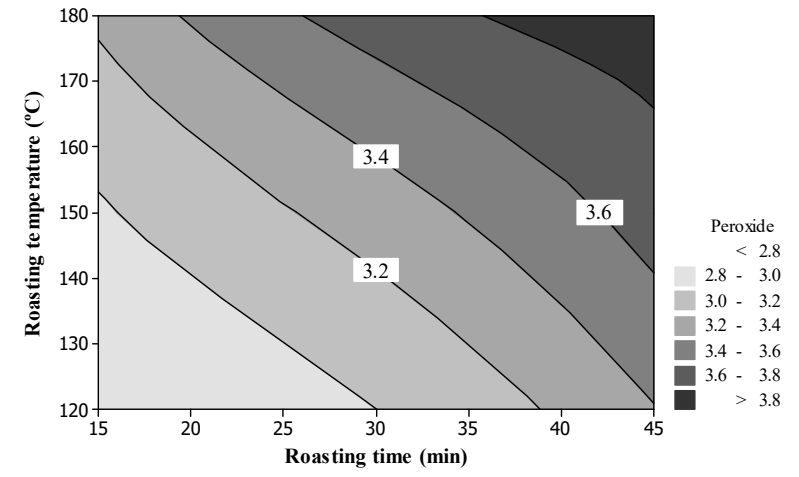

f: Peroxide (meq $\mathrm{O}_{2} / \mathrm{kg}$ ) value of butter

Figure 1. Contour plots showing the effect of roasting time and roasting temperature of shea kernels on some quality characteristics of shea butter

Colour is one of the most important attributes used during the purchase of shea butter. Brightness $\left(\mathrm{L}^{*}\right)$ and yellowness $\left(\mathrm{b}^{*}\right)$ were the colour parameters taken into account for butter colour. The second order regression equation developed for $\mathrm{L}^{*}$ was as follows:

$$
L^{*}=11.8046-0.8429 X_{1}+1.2181 X_{2}-0.004 X_{1}^{2}-0.0055 X_{2}^{2}+0.0073 X_{1} X_{2}
$$

This regression equation for the $L^{*}$ value of butter samples explained $87 \%$ of the variation in the brightness values, which ranged from 57 to 80 , and had a significant lack of fit with a $P$ value of 0.01 . The regression coefficients in Table 2 show that the linear terms of the two factors and the quadratic term of the roasting temperature as well as the interactions between the roasting time and the roasting temperature had a significant influence on the $L^{*}$ value. The contour plots (Figure 1c) showed the gradual decrease of $\mathrm{L}^{*}$ values with the increase of roasting temperature, indicating that the butter samples became darker when the roasting temperature of crushed kernels increased.

Yellowness $\left(b^{*}\right)$ of butter samples was also affected by roasting time and roasting temperature of crushed kernels. The CCFD model developed for $b^{*}$ explained $86 \%$ of the variation of $\mathrm{b}^{*}$ values which varied from 10 to 19 and had a significant lack of fit with a $P$ value of 0.01 . The linear and quadratic terms of roasting temperature significantly influenced the yellowness of butter samples (Table 2). It was observed that the interaction between the roasting time and temperature also significantly influenced the yellowness of butter. The contour plots (Figure 1d) developed for $b^{*}$ by the model showed linear curves with roasting temperature of kernels, irrespective of the roasting time. During roasting, as the temperature increased, butters lost their yellowness, indicated by decreasing $b^{*}$ values.

The FFA percentage is one of the most important quality parameters for oil and fat, which is often used as a general indication of oil conditions (Akoh \& Min 2008). Linear terms, quadratic terms as well as the interaction of the two factors were found to have a significant effect on FFA percentages (Table 2). The regression model linked to FFA percentages was 
following:

$F F A(\%)=7.0019+0.2581 X_{1}-0.1059 X_{2}-0.0016 X_{1}^{2}+0.0004 X_{2}^{2}-0.0011 X_{1} X_{2}$

This model explained $84 \%$ of the variation in FFA percentages. Since the model showed a non-significant lack of fit $(P$ value $=0.16)$, the regression equation explained the variation of the response. For the linear terms, a positive effect was found for the roasting time while a negative effect was found for the roasting temperature. Therefore, an increase in FFA percentage coincided with an increase of roasting time, and lower FFA percentages with an increase in roasting temperature. These results are illustrated by the contour plots that first show a decrease of the FFA percentages with increasing roasting temperature, irrespective of the roasting time; and second, an increase of the FFA percentages with increasing roasting time (Figure 1d). The FFA percentages $(0.5-3 \%)$ were higher than the value of $0.3 \%$ tolerated for cosmetic purposes at international level (Codex Alimentarius, 1992), but lower than the maximum value of $4 \%$ accepted by the Codex Alimentarius for food purposes (Morales et al., 2005). Relatively low FFA percentages were found for the highest roasting temperature, probably due to the total reduction of moisture in the kernels, preventing hydrolysis.

No significant effects of roasting time and temperature were found on the peroxide values as well as the $P$ value of the lack of fit of the model (Table 2). Nevertheless, a slight increase in peroxide values (from $2.8 \mathrm{meq} \mathrm{O}_{2} / \mathrm{kg}$ to $3.8 \mathrm{meq} \mathrm{O}_{2} / \mathrm{kg}$ ) occurred with increasing roasting time and temperature (Figure 1e). As primary products of oxidation, peroxides might be decomposed during oxidation into secondary products viz. hydrocarbons, ketones, aldehydes, furans, which are among the identified volatile compounds (Frankel, 1985; Akoh \& Min, 2008). This degradation might reduce the amount of peroxide, which would explain that no significant effect of roasting conditions on peroxide values was found.

\subsection{Volatile Compounds}

Twenty seven compounds were identified in the samples of shea butter from unroasted kernels, whereas 58 compounds were detected in shea butter from different roasting treatments. These compounds were clustered in 11 groups, among which carbonyls (14 compounds), hydrocarbons (13 compounds) and benzenoid hydrocarbons ( 8 compounds) dominated in terms of numbers (Table 3 ). Compounds in relatively high concentrations were 2-octene (0.1-9.2\%), furfural (0.6-7.1\%), acetic acid (1.4-6.7\%), 5-methyl 2-furancarboxaldehyde (0.5-4.7\%) and hexanal (0.3-2.6\%) (Table 4). Most compounds were also detected by Krist et al. (2006) and Bail et al. (2009a) in shea butter from different regions, and by Bail et al. (2009b) in several nut oils mainly used as food ingredients. Most of the identified compounds were generated by the roasting of the kernels, as apparent from the comparison of volatile components of shea butter from unroasted and roasted kernels: furans, ketones, pyrazines, esters, and phenols were absent in shea butter from unroasted kernels and consequently were generated during the roasting process (Jung et al., 1999). Roasting time significantly influenced the number of compounds $(p=0.001)$; for instance, the number of compounds increased from 28 to 37 when the roasting time increased from 15 to $45 \mathrm{~min}$ at $120{ }^{\circ} \mathrm{C}$. The highest number of volatile compounds was from butter obtained from kernels 


\section{Macrothink}

that were roasted at $180{ }^{\circ} \mathrm{C}$ for $30 \mathrm{~min}$. Furthermore, the relative content of each volatile compound varied with roasting time and roasting temperature. For example, the relative content of acetic acid increased from 1.4 to $6.2 \%$ when the roasting time increased from 15 to $45 \mathrm{~min}$ at $120^{\circ} \mathrm{C}$.

Table 3. Number of identified volatile compounds in shea butter obtained from kernels subjected to different roasting treatments

\begin{tabular}{|c|c|c|c|c|c|c|c|c|c|c|}
\hline \multirow[b]{3}{*}{$\begin{array}{l}\text { Volatile } \\
\text { compounds }\end{array}$} & \multicolumn{9}{|c|}{ Roasting treatments } & \multirow[b]{3}{*}{$\begin{array}{l}\text { Shea butter from } \\
\text { unroasted kernel }\end{array}$} \\
\hline & \multicolumn{3}{|c|}{$120^{\circ} \mathrm{C}$} & \multicolumn{3}{|c|}{$150^{\circ} \mathrm{C}$} & \multicolumn{3}{|c|}{$180^{\circ} \mathrm{C}$} & \\
\hline & $\begin{array}{c}15 \\
\min \end{array}$ & $\begin{array}{c}30 \\
\min \end{array}$ & $\begin{array}{c}45 \\
\min \end{array}$ & $\begin{array}{c}15 \\
\min \end{array}$ & $\begin{array}{c}30 \\
\min \end{array}$ & $\begin{array}{c}45 \\
\min \end{array}$ & $\begin{array}{c}15 \\
\min \end{array}$ & $\begin{array}{c}30 \\
\text { min }\end{array}$ & $\begin{array}{c}45 \\
\min \end{array}$ & \\
\hline Carbonyls & $6^{\mathrm{a}}$ & 9 & 9 & 5 & 11 & 11 & 5 & 12 & 10 & 7 \\
\hline Hydrocarbons & 7 & 7 & 7 & 10 & 8 & 7 & 8 & 7 & 8 & 8 \\
\hline \multicolumn{11}{|l|}{ Benzenoid } \\
\hline hydrocarbons & 6 & 5 & 7 & 6 & 6 & 5 & 7 & 8 & 5 & 5 \\
\hline Furans & 1 & 4 & 3 & 3 & 3 & 3 & 4 & 3 & 4 & 0 \\
\hline Acids & 3 & 4 & 3 & 1 & 4 & 2 & 1 & 2 & 3 & 4 \\
\hline Alcohols & 2 & 1 & 3 & 1 & 3 & 2 & 1 & 2 & 1 & 2 \\
\hline Ketones & 2 & 3 & 4 & 3 & 3 & 3 & 4 & 4 & 3 & 0 \\
\hline \multicolumn{11}{|l|}{ Monoterpene } \\
\hline hydrocarbons & 1 & 1 & 1 & 1 & 1 & 1 & 1 & 1 & 2 & 1 \\
\hline Pyrazines & 0 & 0 & 0 & 0 & 0 & 0 & 0 & 1 & 2 & 0 \\
\hline Esters & 0 & 1 & 0 & 0 & 0 & 0 & 1 & 0 & 0 & 0 \\
\hline Phenols & 0 & 0 & 0 & 0 & 0 & 0 & 0 & 0 & 1 & 0 \\
\hline In total & 28 & 35 & 37 & 30 & 39 & 34 & 32 & 40 & 39 & 27 \\
\hline
\end{tabular}

${ }^{\text {a }}$ Number of volatile compounds. 
Table 4. Relative contents of volatile compounds identified in shea butter obtained from kernels subjected to different roasting treatments

\begin{tabular}{|c|c|c|c|c|c|c|c|c|c|c|c|}
\hline \multirow[b]{3}{*}{ Volatile compounds } & \multirow[b]{3}{*}{$\mathrm{RI}^{\mathrm{a}}$} & \multicolumn{9}{|c|}{ Roasting treatments } & \multirow{3}{*}{$\begin{array}{l}\text { Shea butter from } \\
\text { unroasted kernel }\end{array}$} \\
\hline & & \multicolumn{3}{|c|}{$120^{\circ} \mathrm{C}$} & \multicolumn{3}{|c|}{$150^{\circ} \mathrm{C}$} & \multicolumn{3}{|c|}{$180^{\circ} \mathrm{C}$} & \\
\hline & & $15 \mathrm{~min}$ & $30 \mathrm{~min}$ & $45 \mathrm{~min}$ & $15 \mathrm{~min}$ & $30 \mathrm{~min}$ & $45 \min$ & $15 \mathrm{~min}$ & $30 \mathrm{~min}$ & $45 \mathrm{~min}$ & \\
\hline \multicolumn{12}{|l|}{ Carbonyls } \\
\hline Pentanal & 710 & $0.04^{b}$ & 0.1 & 0.01 & - & 0.01 & 0.01 & - & - & 0.02 & 0.1 \\
\hline Hexanal & 799 & $s^{c}$ & 0.5 & - & - & 2.6 & 0.5 & 0.3 & 2.2 & 1.1 & 1.9 \\
\hline Heptanal & 908 & 0.04 & 0.05 & 0.03 & 0.01 & 0.03 & 0.02 & 0.04 & 0.03 & 0.02 & 0.5 \\
\hline 2-Heptenal,(E)- & 948 & 0.1 & 0.2 & 0.1 & 0.02 & 0.1 & 0.04 & - & 0.8 & - & 0.2 \\
\hline Benzaldehyde & 968 & - & 0.3 & 0.2 & - & 0.3 & 0.2 & - & 0.2 & 0.1 & - \\
\hline Octanal & 1017 & - & 0.01 & 0.005 & - & 0.8 & 0.4 & - & 1.0 & - & - \\
\hline Benzeneacetaldehyde & 1052 & 0.1 & 0.1 & 0.3 & 0.04 & 0.1 & 0.03 & - & - & - & - \\
\hline Nonanal & 1110 & 0.01 & 0.01 & 0.01 & 0.1 & 0.1 & 0.003 & 0.1 & 0.005 & 0.01 & 0.01 \\
\hline 2-Nonenal,(E)- & 1150 & - & - & - & - & 0.01 & 0.04 & - & 0.002 & 0.01 & - \\
\hline 2-Decenal,(E)- & 1201 & 0.05 & 0.002 & 0.001 & 0.001 & 0.1 & 0.0005 & 0.001 & 0.001 & 0.001 & 0.001 \\
\hline Decanal & 1208 & - & - & 0.0001 & - & 0.002 & 0.0007 & - & 0.002 & 0.002 & 0.0005 \\
\hline 2,4-Decadiena1,(E,E)- & 1319 & - & - & - & - & - & - & - & 0.0003 & - & - \\
\hline 2,4-Decandienal & 1328 & - & - & - & - & - & - & - & 0.0004 & 0.1 & - \\
\hline 2-Undecenal & 1378 & - & - & - & - & - & - & - & 0.1 & 0.1 & - \\
\hline Total & & 0.4 & 1.3 & 0.6 & 0.2 & 4.0 & 1.2 & 0.5 & 4.3 & 1.5 & 2.6 \\
\hline \multicolumn{12}{|l|}{ Hydrocarbons } \\
\hline Heptane,4-methyl- & 782 & - & 0.1 & 0.05 & - & 0.1 & 0.1 & 0.4 & 1.2 & 0.03 & - \\
\hline Octane & 811 & 0.6 & 0.4 & 0.3 & 0.5 & 0.6 & 0.1 & 0.2 & 0.2 & 0.1 & 1.2 \\
\hline 2-Octene & 828 & 3.6 & - & - & 4.7 & 0.1 & - & - & - & - & 9.2 \\
\hline 2,4-Dimethyl-1-heptene & 856 & - & 0.03 & 0.02 & 0.1 & 0.1 & 0.01 & 0.1 & 0.1 & 0.04 & - \\
\hline Nonane & 900 & 2.8 & - & - & 1.3 & - & - & - & - & - & 2.6 \\
\hline 1-Decene & 991 & - & - & - & 1.0 & - & - & - & - & - & 2.5 \\
\hline Decane & 1000 & 0.2 & 0.01 & 0.01 & 0.1 & 0.02 & 0.002 & 0.1 & 0.01 & 0.01 & 0.5 \\
\hline Limonene & 1032 & 0.05 & 0.04 & 0.04 & 0.05 & 0.1 & 0.1 & 0.1 & 0.1 & 0.1 & 0.1 \\
\hline 2-Undecene, $(\mathrm{E})$ - & 1087 & - & - & - & - & 0.04 & - & 0.004 & - & - & - \\
\hline Undecane & 1100 & 0.0004 & 0.0004 & 0.001 & 0.0002 & 0.0003 & 0.0004 & 0.001 & - & 0.0003 & 0.0004 \\
\hline Dodecane & 1200 & - & 0.0002 & 0.0001 & 0.0002 & 0.0001 & 0.0001 & 0.0001 & 0.0002 & 0.0001 & 0.0001 \\
\hline Undecane, 2,6-dimethyl- & 1210 & - & - & - & - & - & - & 0.2 & 0.1 & 0.03 & - \\
\hline Tridecane & 1300 & 0.0001 & - & - & 0.0001 & - & - & - & - & - & - \\
\hline Total & & 7.3 & 0.6 & 0.4 & 7.6 & 0.9 & 0.3 & 1.1 & 1.6 & 0.2 & 16.0 \\
\hline
\end{tabular}

${ }^{\mathrm{a}} \mathrm{RI}$ calculated according to the formula: RIx $=100 \mathrm{n} 0+100(\mathrm{RTx}-\mathrm{RTn} 0) /(\mathrm{RTn} 1-\mathrm{RTn} 0)$; wherex is the name of the target compound, $\mathrm{n} 0$ is identified volatile compound directly eluting before $\mathrm{x}, \mathrm{n} 1$ is identified volatile compound directly eluting after $\mathrm{x}, \mathrm{RT}$ is retention time (in min), (http://massfinder.com/wiki/Retention_index_guide)

${ }^{\mathrm{b}}$ The relative content of each volatile compound was evaluated as \% peak area using integration data (percentage related to the total level of volatiles)

${ }^{\mathrm{c}}$ Not detectable.

Independent of the processing steps, volatile compounds in shea butter mainly resulted from degradation of long chain and unsaturated fatty acids by hydrolysis and oxidation reactions. Indeed, at high temperature, hydroperoxides, which are the primary oxidation products of lipids, were decomposed into alkoxy radicals and formed aldehydes, ketones, acids, esters, alcohols, and short-chain hydrocarbons (Frankel, 1985). As one of the degradation products of fatty acids, the relative content of acetic acid is an indicator of the quality of shea butter (Krist et al., 2006). Volatile compounds in shea butter may also result from the Maillard reaction, and typical Maillard products such as furans could be identified. The large numbers of volatile compounds are formed as minor products and many of them are responsible for off-flavours in fats, oils and other lipid-containing foods (Grosch, 1982; Grosch \& Ullrich, 1987). Therefore, the detection of one or more of these compounds has often been used to indicate the early occurrence of oxidation or to obtain an objective assessment of the flavour changes. For example, pentanal, hexanal and 2,4-decadienal, which are formed during the autoxidation of linoleic acid, have been proposed as indicators for the development of 


\section{Mll Macrothink}

off-flavours in vegetable oils (Frankel, 1985; Grosch, 1986). However, hydrocarbons and benzenoid hydrocarbon compounds might not only have resulted from fat oxidation and the Maillard reaction (Farmer \& Mottram, 1990); they could also come from the surface used for the sun-drying of the kernels as this processing operation is generally done on the tar on roadsides, which is a known source of hydrocarbons (Basha et al., 2009).

Finally, when comparing the changes in acid compounds to the FFA percentage of the same samples, differences were observed. These differences might be due to the nature of FFA in shea butter. For instance, the FFA percentage is calculated as the percentage of oleic acid and this fatty acid is not volatile due to its high molecular weight, and thus is not present in the headspace fraction.

\subsection{Optimization of Roasting Process Conditions}

Optimum conditions for the roasting time and roasting temperature are predicted by the CCFD models. A condition is considered optimal if the desirability value associated to the response is 1 or close to 1 (Minitab 16 guide). The desirability value is generally between 0 and 1 and explains the level of validity of the predicted optimum conditions. With the global desirability of 0.8 the RSM model generates the optimal conditions of roasting time of $15 \mathrm{~min}$ and roasting temperature of $171{ }^{\circ} \mathrm{C}$ to get a high fat content ( $49 \% \mathrm{dw}$ or $46 \%$ wet weight) and butter yield (30\% wet weight of kernel mass) as well as low FFA percentage $(0.8 \%)$ and peroxide value $\left(3.2 \mathrm{meq} \mathrm{O}_{2} / \mathrm{kg}\right.$ ). Shea butter with these characteristics is classified as first grade according to the standards set by shea production countries for international trade, and so this butter would be suitable for all purposes, specifically for cosmetic purposes without refining (NB 04.02.001, 2006). An optimum roasting treatment with respect to the presence of volatile compounds cannot be given on the basis of this study as this requires an in-depth olfactory evaluation.

\section{Conclusion}

Roasting time and temperature applied separately or in combination had significant effects on all quality parameters investigated. Longer roasting at higher temperatures yielded more fat while a high roasting temperature resulted shea butter with low FFA percentage. However, it also generated more volatile compounds of which some may have some negative effects on butter flavour. Most of the compounds found were generated during roasting by hydrolysis, oxidation, and the Maillard reaction and some of them contributed to the aroma profile of shea butter. The optimum roasting treatment for crushed shea kernels according to the mathematical model is for $15 \mathrm{~min}$ at a temperature of $171^{\circ} \mathrm{C}$. This mathematically calculated optimum roasting time is shorter than the current practice, suggesting that the use of scarce and expensive firewood during traditional processing is higher than necessary. Therefore it is recommended to test the optimum roasting conditions under field conditions using firewood, and also to assess the effects of these conditions on the unsaponifiable fraction, the sensorial attributes such as colour, flavour, taste, smell, and the nutritional value of shea butter.

\section{Acknowledgements}

The authors greatly thank the Netherlands Universities' Foundation for International Cooperation (NUFFIC) for supporting the scholarship through the NPT/BEN/263 project, hosted at the University of Abomey-Calavi in Benin. The authors also thank Prof. Romain 


\section{MInstitute Macrothink $_{\text {Int }}$}

Glele Kakai for his help in statistical analysis and Ginette Sagbohan for her technical assistance during the study.

\section{References}

Akoh, C. C., \& Min, D. B. (2008). Food lipids, chemistry, nutrition and biotechnology: (3 rd ed.). Florida, CRC Press, Boca Rotan.

Alander, J., \& Andersson, A. C. (2002). The shea butter family-the complete emollient range for skin care formulations. Cosmetics and Toiletries Manufacture Worldwide, 1, 28-32.

AOAC. (2002). Official Methods of Analysis.(16th ed.). Association of Official Analytical Chemists, Washington DC.

Basha, S. A., Gopal, K. R., \& Jebaraj, S. (2009). A review on biodiesel production, combustion, emissions and performance. Renewable and Sustainable Energy Reviews, 13, 1628-1634. https://doi.org/10.1016/j.rser.2008.09.031

Bail, S., Krist, S., Masters, E., Unterweger, H., \& Buchbauer, G. (2009a). Volatile compounds of shea butter samples made under different production conditions in western, central and eastern Africa. Journal of Food Composition and Analysis, 22, 738-744. https://doi.org/10.1016/j.jfca.2009.02.011

Bail, S., Stuebiger, G., Unterweger, H., Buchbauer, G., \& Krist, S. (2009b). Characterization of volatile compounds and triacylglycerol profiles of nut oils using SPME-GC-MS and MALDI-TOF-MS. European Journal of Lipid Science and Technology, 111, 170-182. https://doi.org/10.1002/ejlt.200800007

Bup, N. D., Kapseu, C., Matos, L., Mabiala, B., \& Mouloungui, Z. (2011). Influence of physical pretreatments of sheanuts (Vitellaria paradoxa Gaertner.) on butter quality. European Journal of Lipid Science and Technology, 113, 1152-1160. https://doi.org/10.1002/ejlt.201100005

Choe, E. \& Min, D. B. (2006). Mechanisms and factors for edible oil oxidation. Comprehensive Reviews in Food Science and Food Safety, 5, 169-176. https://doi.org/10.1111/j.1541-4337.2006.00009.x

Codex Alimentarius. (1992). Programme mixte FAO/OMS sur les normes alimentaires FAO, Rome.

Di Vincenzo, D., Maranz, S., Serraiocco, A., Vito, R., Wiesman, Z., \& Bianchi, G. (2005). Regional variation in shea butter lipid and triterpene composition in four African countries. Journal of Agricultural and Food Chemistry, 53, 7473-7479. https://doi.org/10.1021/jf0509759

Elias, M., \& Carney, J. (2004). La filière féminine du karité: productrice burkinabée, «éco-consommatrices» occidentales et commerce équitable. Cahier de géographie du Québec, 48, 71-88. https://doi.org/10.7202/009763ar

Farmer, L. J. \& Mottram, D. S. (1990). Interaction of lipid in the Maillard reaction between cysteine and ribose: effect of a triglyceride and three phospholipids on the volatile products. Journal of the Science of Food and Agriculture, 53, 505-525. https://doi.org/10.1002/jsfa.2740530409

Frankel, E. N. (1985). Chemistry of autoxidation: Mechanism, products and flavor 
significance. In D. B. Min, \& Smouse, T. H. (Eds.), Flavor chemistry of fats and oils (pp 1-34). New-York: American Oil Chemists' Society.

Giovanni, M. (1983). Response Surface Methodology and product optimization. Food Technology, 11, 41-45.

Grosch, W. (1982). Lipid degradation products and flavour. In I. D. Morton, \& MacLeod, A. J. (Eds.), Food flavours, Part (pp. 325-363). Amsterdam: Elsevier Scientific Publ.

Grosch, W. (1986). Reactions of hydroperoxides-products of low molecular weight. In. S. H. W. Chan (Ed.), Autoxidation of unsaturated lipids (pp. 95-112). London: Academic Press.

Grosch, W., \& Ullrich, F. (1987). Identification of important volatile flavor compounds formed during autoxidation of linoleic and linolenic acids. Journal of the American Oil Chemists Society, 64, 624-624.

Honfo, F. G., Linnemann, A., Akissoe, N., Soumanou, M., \& van Boekel, M. A. J. S. (2012). Indigenous knowledge of shea processing and quality perception of shea products in Benin. Ecology of Food and Nutrition, 51, 505-525. https://doi.org/10.1080/03670244.2012.705744

Honfo, F. G., Akissoe, N., Linnemann, A., Soumanou, M., \& van Boekel, M. A. J. S. (2014). Nutritional composition of shea products and chemical properties of shea butter: a review. Critical Review of Food and Nutrition, 54, 673-686. https://doi.org/10.1080/10408398.2011.604142

Jung, M. Y., Bock, J. Y., Baik, S. O., Lee, J. H., \& Lee, T. K. (1999). Effects of roasting on pyrazine contents and oxidative stability of red pepper seed oil prior to its extraction. Journal of Agricultural and Food Chemistry, 47, 1700-1704. https://doi.org/10.1021/jf9810281

Kapseu, C., Bup, N.D., Tchiegang, C., Fon Abi, C., Broto, F. \& Parmentier, M. (2007). Effect of particle size and drying temperature on drying rate and oil extracted yields of Buccholzia coriacea (MVAN) and Butyrospermum parkii ENGL. International Journal of Food Science and Technology, 42, 573-578. https://doi.org/10.1111/j.1365-2621.2006.01277.x

Kassamba, B. (1997). Synthèse des techniques connues d'extraction et de conditionnement du beurre de karité au Burkina Faso. Ouagadougou: Projet filière karité du CECI IRSAT. 9p.

Krist, S., Bail, S., Unterweger, H., Ngassoum, M. B., Mohagir, A. M., \& Buchbauer, G. (2006). Volatile compounds of original African black and white shea butter from Tchad and Cameroon. European Journal of Lipid Science and Technology, 108, 583-588. https://doi.org/10.1002/ejlt.200500340

Krysiak, W. (2002). Roasting conditions and cocoa bean quality. Acta Agrophysic, 77, 51-60.

Krysiak, W., \& Motyl-Patelska, L. (2006). Effect of air parameters on changes in temperature inside roasted cocoa beans. Acta Agrophysic, 7, 113-127.

Lipp, M., \& Adam, E. (1998). Review of cocoa butter and alternative fats for use in chocolate-Part A. Compositional data. Food Chemistry, 62, 73-97.

Maranz, S., \& Wiesman, Z. (2004). Influence of Climate on the Tocopherol Content of Shea Butter. Journal of Agricultural and Food Chemistry, 52, 2934-2937. https://doi.org/10.1021/jf035194r

Masters, E. T., Yidana, J. A., \& Lovett, P. N. (2004). Reinforcing sound management through trade: Shea tree products in Africa. Unasylva, 55, 46-52. 


\section{Macrothink}

Montogomery, D. C. (2001). Design and analysis of experiments. Vol. 5, (5th ed.). New York: John Wiley and Sons.

Morales, M., Luna, G., \& Aparicio, R. (2005). Comparative study of virgin olive oil sensory defects. Food chemistry, 91, 293-301. https://doi.org/10.1016/j.foodchem.2004.06.011

Nawar, W. W. (1998). Biochemical processes: lipid instability. In I. A. Taub, \& Singh, P. R. (Eds.), Food storage stability (pp. 98-112), Washington D.C: CRC Press.

NB 04.02.001. (2006). Beurre de karité non raffiné: spécification. Cotonou: Centre Béninois de Normalisation et de la Gestion de la Qualité (CEBENOR), 9p.

NB ISO 3960. (2006). Normes Béninoises pour les corps gras d'origine animale et végétale: détermination de l'indice de peroxyde. Cotonou: Centre Béninois de Normalisation et de la Gestion de la Qualité (CEBENOR), 9p.

NB ISO 660. (2006). Normes Béninoises pour les corps gras d'origine animale et végétale: détermination de l'indice d'acide et de l'acidité. Cotonou: Centre Béninois de Normalisation et de la Gestion de la Qualité (CEBENOR), 13p.

USAID/WATH. (2005). Guide à l'exportation du beurre de karité. Accra: West Africa Trade Hub (WATH), 21p.

Womeni, H. M. (2004). Identification et analyse des opérations critiques de préparation des fruits, graines et amandes de karité (Butyrospermum parkii (G. Don) Kotschy): étude de leur influence sur la qualité du beurre, Thèse de Doctorat/Ph.D en technologie alimentaire, ENSAI, Université de Ngaoundéré, 170 p.

\section{Copyright Disclaimer}

Copyright for this article is retained by the author(s), with first publication rights granted to the journal.

This is an open-access article distributed under the terms and conditions of the Creative Commons Attribution license (http://creativecommons.org/licenses/by/3.0/). 